\title{
Potential Threat of Bruchids on Soybean Production in Sub-Saharan Africa
}

\author{
Michelle L. Pawlowski, ${ }^{1}$ Doris M. Lagos-Kutz, ${ }^{2,3}$ Michelle da Fonseca Santos, ${ }^{1}$ Nicole Lee, ${ }^{1,3}$ Godfree Chigeza, ${ }^{4}$ \\ Christabell Nachilima, ${ }^{4}$ Josy Helena Merola Botan Francischini, ${ }^{1}$ and Glen L. Hartman ${ }^{2,3,+}$ \\ ${ }^{1}$ Soybean Innovation Laboratory, University of Illinois, Urbana, IL 61801, U.S.A. \\ ${ }^{2}$ United States Department of Agriculture - Agricultural Research Service, Urbana, IL 61801, U.S.A. \\ ${ }^{3}$ Department of Crop Sciences, University of Illinois, Urbana, IL 61801, U.S.A. \\ ${ }^{4}$ International Institute of Tropical Agriculture-IITA, SARAH Campus, Lusaka, Zambia
}

Accepted for publication 17 February 2021.

\section{Abstract}

Soybean production in sub-Saharan Africa (SSA) has been increasing in recent years in part due to the efforts of several national and international research agencies, including the Soybean Innovation Laboratory (SIL). SIL's mission to increase utilization and production of soybean in SSA has led to several facets of research including cultivar development to increase yield through the Pan-African Soybean Variety Trials (PATs). Several abiotic and biotic stresses can decrease yield, including pathogens and pests that attack seed. While evaluating seed lots from 32 PAT locations, we identified bruchids and/or bruchiddamaged seed in nine locations in four countries (Cameroon, Malawi, Mozambique, and Rwanda). The most severe damage and infestation was recorded in Bwanje, Malawi, with 28 of the
40 seed lots infested. Seed damage ranged from 0.6 to $100 \%$ among the 28 infested seed lots. Adult bruchids discovered at the Bwanje location were identified as Callosobruchus chinensis, or the Chinese bruchid. No adults were found in other locations. Bruchids are a destructive storage pest of legumes, and monitoring the different species attacking soybean will help researchers and producers understand the potential threat of bruchids to soybean production in SSA as well as help implement the best management practices.

Keywords: Callosobruchus chinensis, Chinese bruchid, adzuki weevil, Glycine max, infested seed, legumes
The first record of soybean production in sub-Saharan Africa (SSA) was in South Africa in 1903 shortly after soybean was introduced by Chinese traders in the 19th century (Giller and Dashiell 2006). In SSA, soybean is commonly grown by smallholder farmers and has been recommended for production in areas with higher rates of malnutrition because of the exceptional nutritional value of the crop when utilized for human consumption due to its high protein content. The crop has also been used for oil and chicken meal (Khojely et al. 2018). In 2016, 1.5 million hectares were dedicated to soybean production in SSA, with South Africa, Nigeria, and Zambia being the top soybean producing countries (Cornelius and Goldsmith 2019). SSA produces an average of $1.1 \mathrm{t} / \mathrm{ha}$, which is considerably lower than the world average of $2.4 \mathrm{t} / \mathrm{ha}$ (Khojely et al. 2018). The Feed the Future Innovation Lab for Soybean Value Chain Research (https://www.soybeaninnovationlab.illinois.edu/; SIL) has developed a soybean program in SSA to further increase soybean production and utilization in this region. To accomplish this, SIL has a comprehensive research program focusing on multiple facets of increasing yields through soybean cultivar development

${ }^{\dagger}$ Corresponding author: G. L. Hartman; glen.hartman@usda.gov, ghartman@illinois.edu

The author(s) declare no conflict of interest.

This article is in the public domain and not copyrightable. It may be freely reprinted with customary crediting of the source. The American Phytopathological Society, 2021.
(Santos 2019). Through the Pan-African Soybean Variety Trials (PATs), panels of 20 to 40 soybean lines are planted in 17 countries and over 70 locations in SSA to identify the best performing lines for each location. Data from the trials include yield and other agronomic characteristics, seed composition, and disease and pest evaluations. For example, in-season severity of soybean foliar diseases and pest damage was recently published for soybean entries in seven of the PAT locations (Nachilima et al. 2020). Along with in-season evaluations of diseases and pests, it is also important to learn more about soybean seed diseases and pests that affect seed. In our effort to evaluate PAT soybean entries for seed pathogens, we found some of the seeds of the soybean entries with bruchids and associated damage.

\section{Economic Importance of Bruchids in SSA}

Callosobruchus is a genus of beetles commonly referred to as bruchids or weevils. This genus consists of approximately 20 species (Tuda et al. 2006). Bruchids cause considerable damage to pulse crops including adzuki bean, chickpea, cowpea, faba bean, and mung bean and have been reported to infest other leguminous crops such as soybean (CABI 2019). Bruchids are common storage pests worldwide and can cause up to $100 \%$ damage in cowpea under conducive conditions (Ofuya and Reichmuth 1993). Damaged seed is often not usable for planting or human and animal consumption (Kesho 2019). Seed certifications requirements that are used to import and export seeds list both Callosobruchus chinensis and $C$. maculatus as contaminating pests of seeds on plants 
in the Fabaceae (FAO 2017). In Nigeria, $4.5 \%$ of cowpea production is lost annually to bruchid feeding, which is comparable to a loss of US\$30 million (Olakojo et al. 2007). There is little information regarding bruchid damage on soybean, and there is no data on the economic importance of bruchids on soybean production and storage losses.

\section{Bruchid Distribution in Africa}

There are two species of bruchids that are widely distributed throughout Africa and cause significant damage to legumes. The Chinese bruchid (C. chinensis; Coleoptera: Chrysomelidae), commonly known as the adzuki weevil, originated in Asia and spread to other subtropical and tropical regions, with the initial African records occurring in Egypt, Kenya, and Sierra Leone in 1978 (Hammad 1978; Khamala 1978; Taylor 1978). The Chinese bruchid has been identified in nine countries primarily on pulses on the Eastern coast of SSA (CABI 2019). The cowpea bruchid (C. maculatus; Coleoptera: Chrysomelidae), or cowpea weevil, originated in Africa and has been identified primarily on cowpea in 18 countries (Khojely et al. 2018). Bruchids are a major pest of legumes (Udayagiri and Wadhi 1989); however, little is known about their distribution and impact on soybean. The objective of this research was to identify and record the occurrence of bruchids and their seed damage from seed lots obtained from soybean entries in the PATs.

\section{Survey of Bruchid Damage in PAT}

In September 2019, seed samples from 32 PAT locations spanning six countries were shipped to SIL at the University of Illinois in Urbana, IL (Fig. 1; Table 1). Each location had test plots of 23 to 40 soybean entries and about 300 seeds per entry per two replications. An evaluation of these seeds was conducted to assess for the presence of bruchids and/or bruchid-damaged seeds. Seed samples were primarily stored at $4^{\circ} \mathrm{C}$ prior to evaluation except when seed was in transit and during the assay period.

Bruchids or their associated damage were recorded in 10 of the 32 locations (Table 1). The heaviest infestation was from Bwanje, Malawi, where bruchids or their associated damage were identified in 28 of the 46 experimental units (23 soybean entries $\times 2$ replications). Within the 28 seed lots, observed seed damage ranged from 0.6 to $100 \%$ (average $7.9 \%$ ) per experimental unit. Adult bruchids were found infesting 19 of the 46

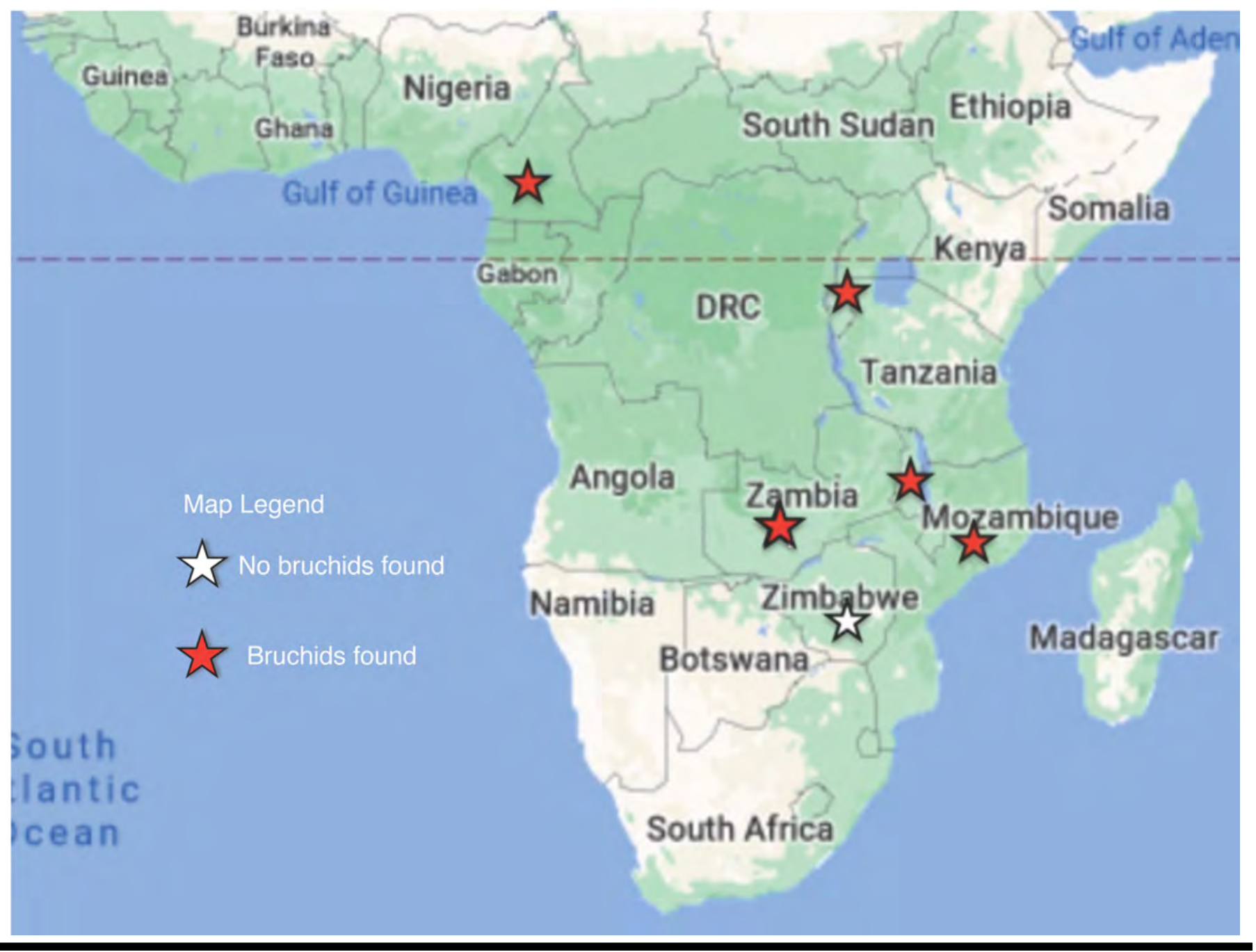

FIGURE 1

Map of sub-Saharan Africa showing countries with red stars where bruchid adults, eggs, or seed damage were found. White stars indicate seed lots where no bruchids were found from the 2018 and 2018/2019 growing seasons of the Pan-African Soybean Variety Trials. 
experimental units from this location, with one to 37 adults (average 11) found per experimental unit.

The bruchids collected on seeds from Bwanje were morphologically identified by following the invasive species compendium description (CABI 2019). The adult size of $C$. chinensis varies between 3.5 and $5 \mathrm{~mm}$. The antennae are pectinate in the male (Fig. 2A) and serrate in the female (Fig. 2B). The elytra are pale brown, with small median dark marks and larger posterior dark patches, which may merge to make the entire posterior part of the elytra dark in color. The side margins of the abdomen have distinct patches of coarse white setae (Fig. 2E and F). C. chinensis has a pair of distinct ridges (inner and outer) on the ventral side of each hind femur, and each ridge has a tooth near the apical end (Fig. 2C). The inner tooth is slender, rather parallelsided, and equal to (or slightly longer than) the outer tooth (Fig. 2D) (CABI 2019). Specimens were deposited at the Illinois Natural History Survey and voucher numbers assigned as 830,676 to 830,681 . At other locations, bruchids or associated damage were less than that found at Bwanje. The amount of bruchid damage and/or eggs was identified in six seed lots each from Mbalmayo and Yaounde in Cameroon; four and 10 seed lots from Chitala and Mpale, respectively, in Malawi; two seed lots from Chipata in Zambia; two each from Gurue and Phoenix in Mozambique; and two seed lots from Nyagatare in Rwanda. No adult bruchids were found in these locations, and species identification was not confirmed. After the evaluations, the infested seeds were placed in the freezer at $-80^{\circ} \mathrm{C}$ for $30 \mathrm{~h}$ to kill all living bruchid morphs.

\section{Biology and Life Cycle of Bruchids}

The complete life cycle of a bruchid lasts from one to several months depending on environmental conditions (CABI 2019). Adult bruchids usually do not feed and have shorter lifespans of up to 12 days under optimum conditions. Females will commonly burrow into mature pods in the field and lay eggs on seed coats. The eggs are small (0.55 $\mathrm{mm}$ long), oval, white, and translucent after egg hatch (Fig. 3A) (Fox 1993). Cowpea bruchids prefer higher oviposition temperatures of 30 to $35^{\circ} \mathrm{C}$ and lay up to 115 eggs, whereas Chinese bruchids prefer a cooler oviposition temperature of $23^{\circ} \mathrm{C}$ and lay up to 70 eggs (CABI 2019). Within 5 to 6 days after oviposition, eggs hatch and larva eat through the seed coat, burrow into the seed, and feed on the cotyledon, making the seed non-viable (Fig. 3B and C). Bruchid larva pass through four instars within the seed before emerging as adults (Fig. 3D) (Bellows 1982). At the final instar, their presence can be detected by a large "gray" window through the seed coat (Fig. 3A). On soybean, it takes between 35 and 60 days for $C$. maculatus (Sharma and Thakur 2014b) and 27 to 37 days for $C$. chinensis to develop from a first instar into an adult (Rajguru et al. 2006). Both species have optimal conditions for development at $32^{\circ} \mathrm{C}$ and $90 \%$ relative humidity. Upon maturation, the

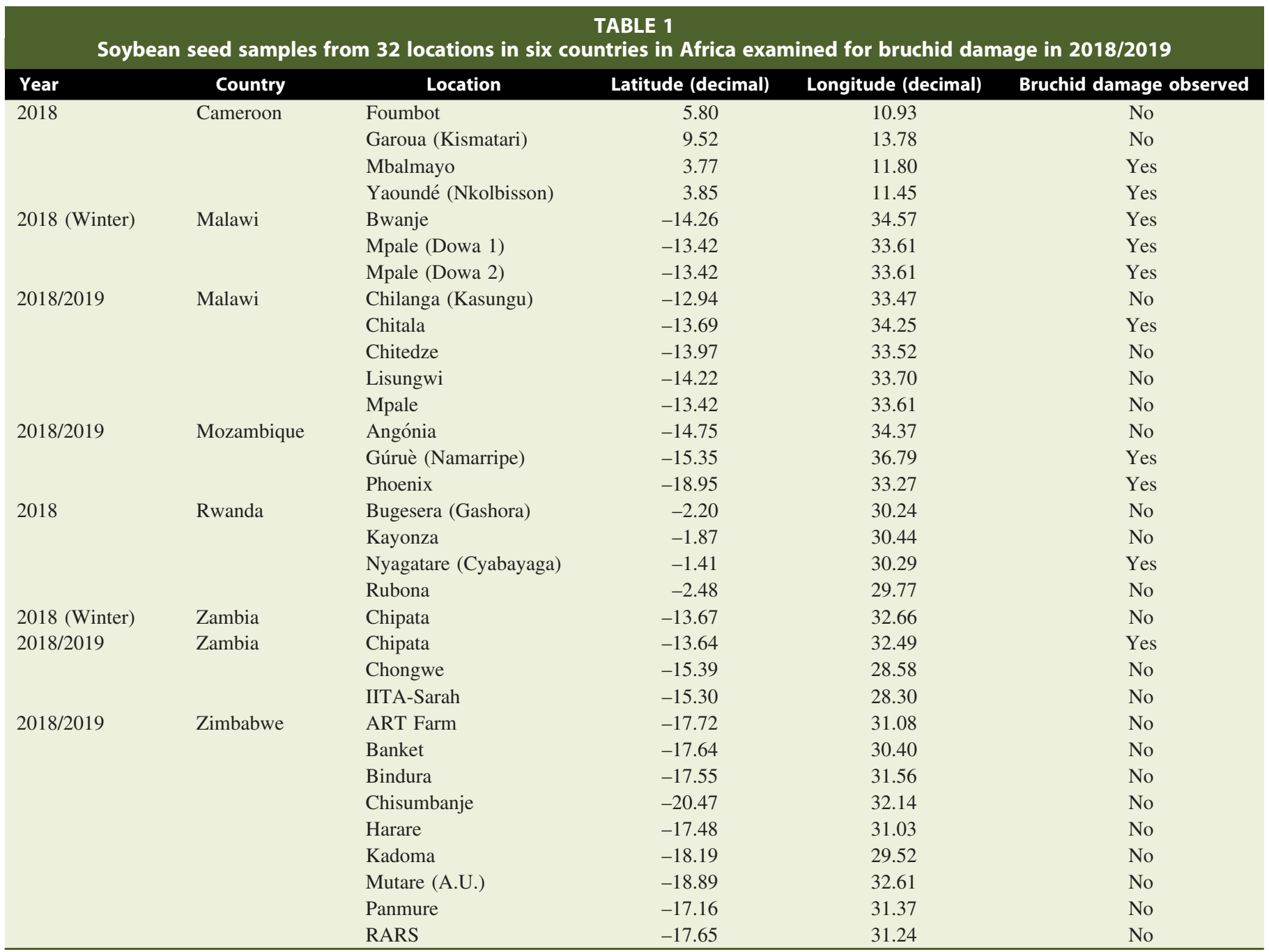


adult bruchid makes a circular hole to exit the seed (CABI 2019). This exit hole in the seed is the most distinct characteristic produced by bruchids and confirms their infestation (Fig. 3D). Depending on conditions, adults will mate and start a secondary infestation cycle (Kesho 2019).

\section{Bruchid Resistance in Soybean}

Breeding legumes for resistance to pests relies on antibiosis or antixenosis (Keneni et al. 2011). Morphological, physiological, or biochemical properties of a host can result in antibiosis resistance, which directly affects the biology of the pest, or by antixe-
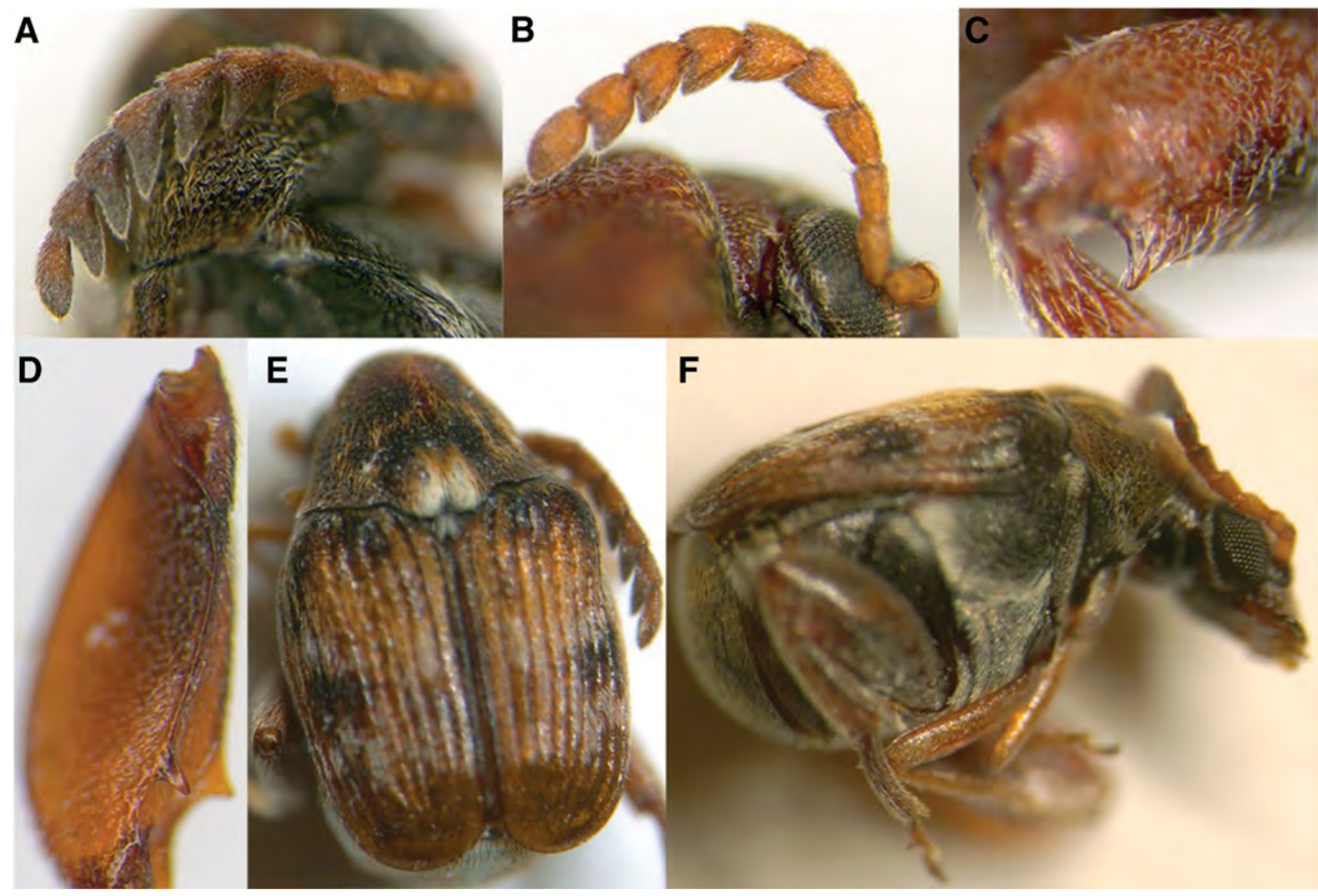

\section{FIGURE 2}

Morphological characters to distinguish Callosobruchus chinensis (Chinese bruchid): A, pectinate antennae of male; B, serrate antennae of female; C, distinguishing ridges (inner and outer) on the ventral side of the hind femur, and each has a tooth near the apical end; $\mathbf{D}$, dorsal view of the hind femur showing the outer tooth; $\mathbf{E}$, dorsal view of the adult showing dorsal patches on elytra and white hairs on thorax; and $\mathbf{F}$, lateral view of a female adult showing that the elytra is slightly shorter than the abdomen. Images A, B, C, and D were magnified 76.1x, 77.6x, 108.6x, and 87.7x, respectively. Images E and F were magnified 30.5x. (Photos by D. Lagos-Kutz).
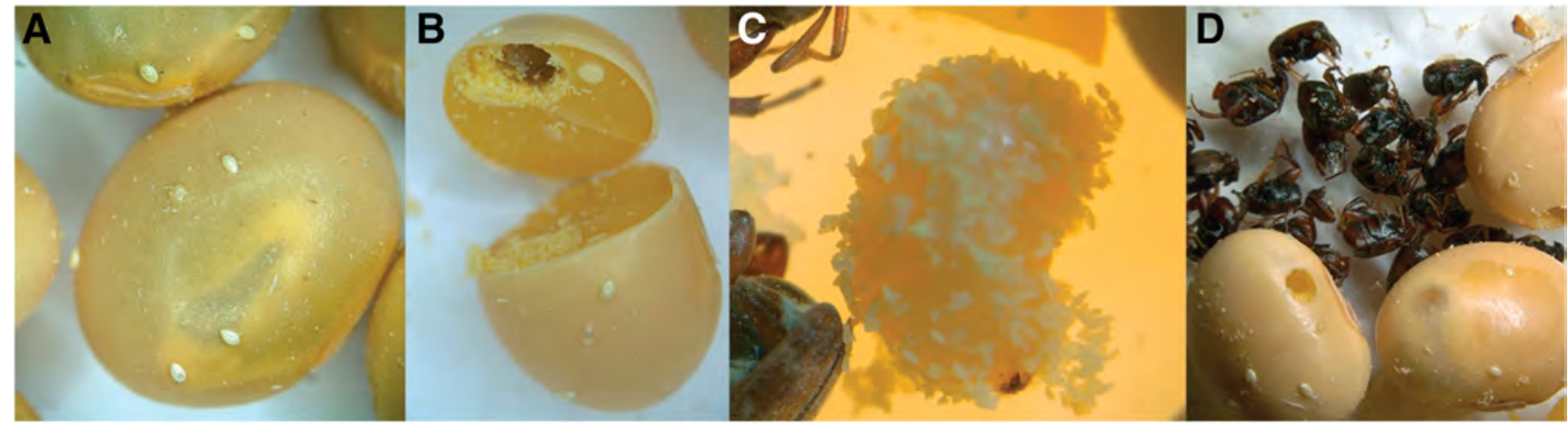

\section{FIGURE 3}

Images of different life stages of Callosobruchus chinensis: A, eggs on soybean seeds; B, soybean seed damaged by C. chinensis; C, larvae covered with seed residual; and $\mathbf{D}$, adults and damaged soybean seeds. Image $A$ was magnified $30.5 \times, B$ and $C$ were magnified 18x, and D was magnified 14.8x. (Photos by D. Lagos-Kutz). 
nosis resistance, which is a nonpreference type of resistance to the pest (Smith 1989). Both types of resistance against bruchids were considered important in soybean (Msiska et al. 2018b; Osman et al. 1991; Rajguru et al. 2006).

Several moderately resistant sources in soybean to $C$. chinensis infestation were identified based on adult emergence, seed weight loss, median development period, and growth index (Msiska et al. 2018b). A follow-up genetic study determined inheritance was additive, nonadditive, or maternal in nature (Msiska et al. 2018a). These soybean cultivars with moderate resistance to bruchids were associated with higher levels of tannins, peroxidases, and antioxidants, whereas more susceptible cultivars were associated with higher flavonoid concentrations (Msiska et al. 2019). Another study found varietal differences in preference ranging from 10 to $65 \%$ seed infestation as well as adult emergence (33 to 67\%) and seed weight loss (20 to 47\%); the study concluded that regardless of varietal preference, genotypes with thicker seed coats had significantly less seed weight loss (Rajguru et al. 2006).

Less extensive work has been reported for soybean resistance to the cowpea bruchid. Thirteen soybean cultivars were screened for their response to cowpea bruchid infestation, and adult emergence ranged from 0 to $17 \%$ and seed weight loss ranged from 0 to $11 \%$ (Sharma and Thakur 2014b). One cultivar, Bragg, was found to be completely resistant to infestation by $C$. maculatus. In contrast, Bragg was found to be susceptible to infestation by C. chinensis with $33 \%$ adult emergence and $23 \%$ weight loss (Rajguru et al. 2006). A follow-up study determined soybean genotypes that were found to be moderately resistant to either species had higher levels of phenols and trypsin inhibitor units compared with more susceptible soybean genotypes and highly susceptible chickpea and cowpea genotypes (Sharma and Thakur 2014a). Although our study had up to 40 genotypes at one location, our findings were based on natural infestation, and no differences between genotypes were observed.

\section{Other Management Methods}

Biological, chemical, and cultural control methods may reduce bruchid damage in legume crops such as soybean (Kesho 2019). Organophosphates, numerous plant extracts, and some pre- and postharvest insecticides are known to have antibruchid properties. The phytochemical azadirachtin from neem is commonly used in India as both an oviposition deterrent and insecticide (Lale and Kabeh 2004; Raguraman and Singh 1997). Several seed protectants were found to be effective on soybean, including essential oils (neem, castor, and pongam), leaf powders (neem, eucalyptus, and pongam), and synthetic insecticides (deltamethrin $2.8 \mathrm{EC}$, cypermethrin $10 \mathrm{EC}$, spinosad $45 \mathrm{SC}$, and fenvalerate 20 EC) used under storage conditions (Choudhary et al. 2014). Because most crops are infested in the field and then carried over into storage, intercropping with a nonhost, such as maize, and timely harvesting can significantly reduce the level of infestation (Olubayo and Port 1997).

\section{Conclusion}

Bruchids are a serious threat to agricultural production in Africa; however, little is known about their distribution and impact on soybean production in SSA. We identified bruchid damage in nine locations throughout SSA while evaluating seed from 32 PAT locations and recorded considerable damage at one location in Bwanje, Malawi. Although we only identified C. chinensis in our study, it seems likely that continued monitoring for different species may be important, because bruchid species may have different impacts and hosts and may require different approaches to management including chemical, cultural, and host resistance that may be needed to reduce seed losses.

\section{Acknowledgments}

The authors thank the Soybean Innovation Lab for collaboration on this research, as well as its partners at the International Institute of Tropical Agriculture (IITA), the Syngenta Foundation for Sustainable Agriculture (SFSA), and the African Agricultural Technology Foundation (AATF). We also acknowledge Emily Gordon for her help evaluating seed lots from the 32 PAT locations.

\section{Literature Cited}

Bellows, T. 1982. Analytical models for laboratory populations of Callosobruchus chinensis and C. maculatus (Coleoptera, Bruchidae). J. Anim. Ecol. 51:263-287.

CABI. 2019. Callosobruchus chinensis (Chinese bruchid) datasheet. CABI Invasive Species Compendium. https://www.cabi.org/isc/datasheet/10986. Accessed July 15, 2020.

Choudhary, S., Bharpoda, T., and Deb, S. 2014. Grain/seed protectants against Callosobruchus chinensis (L.) on soybean, Glycine max (L.) Merrill under storage conditions. Pestic. Res. J. 26:56-62.

Cornelius, M., and Goldsmith, P. 2019. The state of soybean in Africa: Soybean yield in Africa. farmdoc daily 9:221.

FAO. 2017. International movement of seeds. ISPM 38. International Standards for Phytosanitary Measures (ISPM), Produced by the Secretariat of the International Plant Protection Convention.

Fox, C. W. 1993. The influence of maternal age and mating frequency on egg size and offspring performance in Callosobruchus maculatus (Coleoptera: Bruchidae). Oecologia 96:139-146.

Giller, K., and Dashiell, K. 2006. Glycine $\max$ (L.) Merr. Plant Resour. Trop. Afr. 1:76-82.

Hammad, S. 1978. Pests of grain legumes and their control in Egypt. Pages 135137 in: Insect Pests of Grain Legumes and Their Ecology. S. R. Singh, T. Ajibola, and H. F. van Emden, eds. Academic Press, London, U.K.

Keneni, G., Bekele, E., Getu, E., Imtiaz, M., Damte, T., Mulatu, B., and Dagne, K. 2011. Breeding food legumes for resistance to storage insect pests: Potential and limitations. Sustainability 3:1399-1415.

Kesho, A. 2019. A review on integrated management of Callosobruchus chinensis (Coleoptera: Bruchidae) on faba bean. Int. J. Novel Res. Life Sci. 6:1-9.

Khamala, C. 1978. Pests of grain legumes and their control in Kenya. Pages 127-134 in: Insect Pests of Grain Legumes and Their Ecology. S. R. Singh, T. Ajibola, and H. F. van Emden, eds. Academic Press, London, U.K.

Khojely, D. M., Ibrahim, S. E., Sapey, E., and Han, T. 2018. History, current status, and prospects of soybean production and research in sub-Saharan Africa. Crop J. 6:226-235.

Lale, N., and Kabeh, J. 2004. Pre-harvest spray of neem (Azadirachta indica A. Juss) seed products and pirimiphos-methyl as a method of reducing field infestation of cowpeas by storage bruchids in the Nigerian Sudan savannah. Int. J. Agric. Biol. 6:987-993.

Msiska, U. M., Hailay, M. G., Miesho, B. W., Ibanda, A. P., Tukamuhabwa, P., Kyamanywa, S., Odong, T. L., and Rubaihayo, P. 2018a. Genetics of resistance in F2 soybean populations for adzuki bean bruchid (Callosobruchus chinensis). J. Agric. Sci. 10:171-184.

Msiska, U. M., Miesho, B. W., Hailay, M., Kyamanywa, S., Rubaihayo, P., Odong, T. L., Tukamuhabwa, P., Nuwamanya, E., and Nabirye, D. L. 2019. Biochemicals associated with Callosobruchus chinensis resistance in soybean. Afr. J. Rural Dev. 3:859-868.

Msiska, U. M., Odong, T., Hailay, M., Miesho, B., Kyamanywa, S., Rubaihayo, P., and Tukamuhabwa, P. 2018b. Resistance of Uganda soybean germplasm to adzuki bean bruchid. Afr. Crop Sci. J. 26:399-415.

Nachilima, C., Chigeza, G., Chibanda, M., Mushoriwa, H., Diers, B. W., Murithi, H., and Hartman, G. L. 2020. Evaluation of foliar diseases for soybean entries in the Pan-African Trials in Malawi and Zambia. Plant Dis. 104:2068-2073.

Ofuya, T., and Reichmuth, C. 1993. Control of two bruchid pests of stored grain legumes in a nitrogen atmosphere. Crop Prot. 12:394-396.

Olakojo, S., Ayanwole, J., and Obasemola, V. 2007. Laboratory screening of seeds of some cowpea cultivars (Vigna unguiculata) for tolerance to 
cowpea beetles (Callosobruchus maculatus) in a hot humid environment. Am.-Eurasian J. Agric. Environ. Sci. 2:528-533.

Olubayo, F., and Port, G. 1997. The efficacy of harvest time modification and intercropping as methods of reducing the field infestation of cowpeas by storage bruchids in Kenya. J. Stored Prod. Res. 33:271-276.

Osman, N., Ibrahim, R., and Johari, A. 1991. Damage assessment on stored mungbean Vigna radiata (L.) Wilczek and soyabean Glycine max L. Merr. infested with the common bean weevil Callosobruchus maculatus F. (Coleoptera: Bruchidae). Pertanika 14:27-30.

Raguraman, S., and Singh, D. 1997. Biopotentials of Azadirachta indica and Cedrus deodara oils on Callosobruchus chinensis. Int. J. Pharmacogn. 35:344-348.

Rajguru, M., Sharma, A. N., and Pal, A. 2006. Developmental behaviour of pulse beetle, Callosobruchus chinensis (Linn.) on some soybean varieties and their resistance status. Soybean Res. 4:28-32.

Santos, M. 2019. The state of soybean in Africa: Soybean varieties in SubSaharan Africa. farmdoc daily 9:155.
Sharma, S., and Thakur, D. 2014a. Biochemical basis for bruchid resistance in cowpea, chickpea and soybean genotypes. Am. J. Food Technol. 9:318324.

Sharma, S., and Thakur, D. 2014b. Comparative developmental compatibility of Callosobruchus maculatus on cowpea, chickpea and soybean genotypes. Asian J. Biol. Sci. 7:270-276.

Smith, C. M. 1989. Plant Resistance to Insects: A Fundamental Approach. Wiley, New York, NY.

Taylor, W. 1978. Recent trends in grain legume pest research in Sierra Leone. Pages 93-98 in: Insect Pests of Grain Legumes and Their Ecology. S. R. Singh, T. Ajibola, and H. F. van Emden, eds. Academic Press, London, U.K. Tuda, M., Rönn, J., Buranapanichpan, S., Wasano, N., and Arnqvist, G. 2006. Evolutionary diversification of the bean beetle genus Callosobruchus (Coleoptera: Bruchidae): Traits associated with storedproduct pest status. Mol. Ecol. 15:3541-3551.

Udayagiri, S., and Wadhi, S. R. 1989. Catalog of Bruchidae. Mem. Am. Entomol. Inst. 45:1-301. 